\title{
Model pelayanan air bersih perdesaan
}

\section{The model of rural area clean water services}

\author{
Rini Dorojati, Nuraini Dwi Astuti, \& Hartono
}

\author{
Sekolah Tinggi Pembangunan Masyarakat Desa "APMD” \\ Jalan Timoho No. 317 Yogyakarta, Telephone 0274561071 \\ E-mail: rinidorojati21@gmail.com, rinidorojati@yahoo.com
}

\begin{abstract}
Low coverage of clean water in Indonesia leads to minimum consumption of clean water with proper health requirement. Increasement of clean water coverage is undergoing an effort from independent community in society. This research aims to find a service model of clean water for group based rural communities. Type of this research is descriptive qualitative, with research object is clean water independent provider group, Oyo Wening Santosa community, in a village called Bunder, district of Patuk, Gunung Kidul. Data was gathered by document utilization, parsitipatory observation, in-depth interview, and focus group discussion. Data was analyzed with qualitative method. This research shows that clean water coverage organized by communiy Oyo Wening is a model of sinergy for organization that was established by concern from society and government support, emerge in a program called "Sistem Penyediaan Air Minum Ibu Kota Kecamatan" (SPAM IKK). There are 1170 households channel subscribers spread across four villages. The service procedures are applied based on local conditions. This service has some drawbacks, namely the limited knowledge of the officer, the legality of which is not owned by the organization, facilities and infrastructure, and the relatively low tarrif, Rp 3,500 $\mathrm{per} \mathrm{m}^{3}$. In conclusion, rural water services with the model applied in Oyo Wening Sentosa showed a changing trend in people's access to clean water and the local economy has increased. The legality of the business management of water services should become a priority for the stakeholders to ensure the realization of excellent service in providing clean water.
\end{abstract}

Keywords: services, clean water, rural area

\begin{abstract}
Abstrak
Rendahnya cakupan pelayanan air bersih menyebabkan masih banyak masyarakat yang mengkonsumsi air tidak memenuhi layak kesehatan. Salah satu upaya meningkatkan cakupan pelayanan dengan membentuk kelompok swadaya masyarakat. Tujuan penelitian ini untuk menemukan model pelayanan air bersih bagi masyarakat perdesaan berbasis kelompok. Penelitian ini termasuk penelitian deskriptif kualitatif, sebagai obyek penelitian adalah penyelenggara pelayanan air bersih kelompok swadaya masyarakat Oyo Wening Sentosa di Desa Bunder Kecamatan Patuk Kabupaten Gunungkidul. Pengumpulan data dengan pemanfaatan dokumen, pengamatan partisipatif, wawancara mendalam dan FGD. Analisis hasil penelitian dilakukan dengan metode kualitatif. Pelanggan sebanyak 1170 saluran rumah tangga yang tersebar di empat desa. Prosedur pelayanan diterapkan berdasar kondisi masyarakat setempat, sehingga menjadi salah satu pendukung kelangsungan pelayanan air bersih perdesaan. Terbatasnya pengetahuan petugas, legalitas organisasi belum dimiliki, sarana dan prasarana terbatas, dan tarif yang relatif rendah $\mathrm{Rp} 3.500$ per $\mathrm{m}^{3}$ merupakan kelemahan dalam pelayanan. Hasil penelitian menunjukkan bahwa pelayanan air bersih yang diselenggarakan oleh kelompok swadaya masyarakat Oyo Wening Sentosa merupakan model sinergi antara organisasi yang dibentuk atas kepedulian masyarakat dan dukungan pemerintah berupa program Sistem Penyediaan Air Minum Ibu Kota Kecamatan (SPAM IKK). Simpulan penelitian ini menunjukkan bahwa kegiatan pelayanan air bersih perdesaan dengan model pelayanan yang diterapkan Oyo Wening Sentosa menunjukkan peningkatan akses masyarakat terhadap air bersih, dan ekonomi masyarakat juga meningkat. Pemenuhan legalitas adalah penting, maka legalitas pengelolaan usaha pelayanan air bersih menjadi prioritas bagi pihak-pihak pemangku kepentingan agar pelayanan prima segera terwujud.
\end{abstract}

Kata kunci: pelayanan, air bersih, perdesaan 


\section{Pendahuluan}

Undang-undang Nomor 7 Tahun 2004 tentang Sumber Daya Air antara lain menyebutkan bahwa air merupakan kebutuhan dasar manusia yang harus tersedia dalam jumlah dan kualitas yang layak dan memadai sehingga dapat memenuhi kehidupan manusia untuk dapat hidup sehat, bersih dan produktif. Amanat undang-undang tersebut sampai dengan tahun 2015 masih jauh dari harapan karena berbagai kendala dalam mewujudkannya. Hal tersebut diketahui dari data MDGs yang ditargetkan pada tahun 2015 sebanyak 80 persen masyarakat terakses air bersih. Namun kenyataan wakil menteri PU menyatakan bahwa pemerintah baru perlu kerja keras untuk memenuhi target akses aman dalam pelayanan air minum sebesar 68,9 persen pada 2015 (Sony 2014). Kabupaten Gunungkidul merupakan wilayah DIY yang sering mengalami kendala penyediaan air bersih karena kondisi geografis yang pegunungan dan kawasan karst. Upaya yang dilakukan masyarakat setempat di antaranya membentuk kelompok-kelompok swadaya untuk mengatasi pemenuhan kebutuhan air bagi kesejahteraan masyarakatnya. Kondisi tersebut telah dilaksanakan oleh salah satu anggota Paguyuban Air Minum Masyarakat Yogyakarta (Pamaskarta) Unit SPAM Oyo Wening Sentosa yang merupakan salah kelompok swadaya masyarakat berlokasi di desa Bunder Kecamatan Patuk Kabupaten Gunungkidul. Kelompok tersebut telah memanfaatkan potensi sumber daya alam lokal dengan mengeksploitasi sumber air Sungai Oyo yang memiliki debit sebanyak 20 liter per detik dengan kapasitas layanan berdasarkan asumsi pemakaian untuk 2.000 Kepala Keluarga. Sampai dengan bulan Oktober 2015 sudah melayani sebanyak 1170 KK. Berdasarkan program rencana pengembangan ke depan sumber air ini diharapkan dapat mencukupi kebutuhan masyarakat di empat desa di wilayah Kecamatan Patuk, yaitu Beji, Putat, Ngoro-oro dan Desa Patuk.

Bertambahnya jumlah pelanggan yang memperoleh layanan air bersih menuntut SPAM IKK Oyo Wening Sentosa memberikan layanan yang memadai. Beberapa kendala yang dihadapi dalam pelayanan air bersih antara lain sumber daya manusia dalam pelayanan masih terbatas kemampuannya, kondisi alam dengan topografi pegunungan, kemampuan warga penerima manfaat atau pelanggan dalam memberikan kontribusi pelayanan air bersih secara ekonomi pada umumnya rendah dan resiko kebocoran atau kerusakan pipa cukup tinggi. Di satu sisi bahwa dalam pelayanan air sistem perpipaan membutuhkan biaya atau modal yang cukup tinggi. Oleh karena itu, mengetahui model pelayanan air bersih perdesaan yang dilaksanakan kelompok swadaya masyarakat Oyo Wening Sentosa menjadi fokus dalam penelitian ini. Permasalahan yang dapat dirumuskan dalam penelitian ini adalah sebagai berikut: Bagaimana model pelayanan air bersih yang dilaksanakan kelompok swadaya masyarakat Oyo Wening Sentosa di Desa Bunder Kecamatan Patuk? Faktor-faktor apa saja yang menghambat maupun mendukung dalam model pelayanan air bersih yang diterapkan oleh Kelompok Swadaya Masyarakat Oyo Wening Sentosa?

\section{Metode Penelitian}

Penelitian ini termasuk penelitian deskriptif kualitatif untuk mencari solusi penyelesaian masalah pelayanan air bersih perdesaan dalam memenuhi kebutuhan masyarakat khususnya pada lokasi penelitian. Subyek penelitian: pengelola/pengurus dan masyarakat pengguna/pelanggan, tokoh masyarakat, pemerintah kelurahan, dan Dinas Pekerjaan Umum. Teknik Pengumpulan Data 1) dokumentasi; Teknik ini dilakukan dengan cara pengumpulan data sekunder tentang pelayanan air bersih, jumlah anggota, aktivitas, struktur, pendanaan, pengelolaan dan pembinaan pengelola air bersih perdesaan, 2) observasi partisipasi yang dilakukan melalui pengamatan secara langsung terhadap proses kegiatan pengelolaan air bersih yang sedang berjalan dan pemanfaatannya, 3) wawancara mendalam yang dilakukan secara langsung dengan pengelola/pengurus lembaga penyedia air bersih dan pelanggan, tokoh masyarakat, pemerintah kelurahan, dan instansi terkait dalam hal ini dinas pekerjaan umum, 4) focus Group Discussion (FGD) yang dilakukan dengan berbagai stakeholders untuk menggali permasalahan pengelolaan air bersih dan sekaligus mencari kemungkinan solusi dari perspektif mereka. Penelitian ini dilakukan di lembaga pengelola air bersih Oyo Wening Sentosa di Desa Bunder, Kecamatan Patuk 
Kabupaten Gunung Kidul. Analisis Data, hasil penelitian dilakukan dengan analisis kualitatif. Analisis data kualitatif adalah upaya yang dilakukan dengan jalan bekerja dengan data, memilah-milahnya menjadi satuan yang dapat dikelola, mensintesiskannya, mencari dan menemukan pola, menemukan apa yang penting dan apa yang dipelajari, dan memutuskan apa yang dapat diceritakan kepada orang lain (Moleong 2006). Adapun langkah-langkah analisis dalam penelitian ini adalah: 1) mengumpulkan data hasil wawancara mendalam, FGD, pengamatan dan pemanfaatan dokumen, 2) melakukan analisis parsial masing-masing bagian atas hasil wawancara mendalam, FGD, pengematan dan pemanfaatan dokumen, 3) melakukan analisis komprehensif dengan mensintesiskan antar satu bagian dengan bagian lainnya 4) menarik simpulan awal, 5) memverifikasi simpulan dengan obyek yang diteliti dan simpulan akhir, dan 6) membuat rekomendasi.

\section{Hasil Penelitian dan Pembahasan}

Keadaan Geografis, Desa Bunder merupakan salah satu desa di wilayah Kecamatan Patuk, Kabupaten Gunung Kidul, Daerah Istimewa Yogyakarta. Jarak Desa Bunder dengan pusat pemerintahan di atasnya sebagai berikut: dari Pusat Pemerintahan Kecamatan 7 Km, dari Ibukota Kabupaten 13 Km, dari Ibukota provinsi $26 \mathrm{Km}$, dari Ibukota Negara: $720 \mathrm{Km}$. Ketinggian dari permukaan laut: 200-300m, curah hujan: $30 \mathrm{~mm} /$ tahun. Suhu udara (rata-rata): $32^{0}$ C. Secara administratif, Desa Bunder terbagi menjadi 7 pedukuhan. Jumlah penduduk sebanyak 2.892 jiwa terdiri dari laki-laki 1.406 jiwa $(48,62 \%)$ dan perempuan sebanyak 1.486 jiwa (51,38 \%). Dari jumlah penduduk tersebut tercakup ke dalam 895 Kepala Keluarga, atau setiap KK rata-rata terdiri dari 3 jiwa. Lembaga kemasyarakatan desa cukup bervariasi seperti PKK, Karang taruna dan lembaga di setiap wilayah administratif seperti RW, RT maupun Pedukuhan, Kelompok Tani, Kelompok Pengajian dan kelompok olahraga seperti volley, dan sepakbola. Keadaan Ekonomi, masyarakat Desa Bunder sebagian besar bekerja sebagai petani sebanyak 85 persen. Selain sebagai petani, masyarakat Desa Bunder memiliki usaha sampingan seperti pedagang, pengrajin, jasa ojek, jasa angkut/bongkar material, pengrajin kayu, pertukangan, perikanan darat, buruh, dan hasil kerja anggota keluarga di perantauan. Usaha tanaman buah-buahan seperti mangga, rambutan dan kakao dilakukan masyarakat desa ini untuk memanfaatkan lahan juga sebagai penambah pendapatan. Berbagai sarana dan prasarana kehidupan tersedia di Desa Bunder di antaranya di bidang kesehatan, ibadah, perhubungan, pendidikan, dan sarana air bersih. Sarana dan Prasarana Transportasi cukup bervariasi, tiga wilayah Desa Bunder dilalui jalan nasional arah Yogyakarta-Wonosari kurang lebih 1,5 Km, jalan Provinsi yaitu Sambipitu-Nglipar sepanjangkurang lebih 1 Km, jalan Kabupaten yaitu Sambipitu-Gunung Nglanggeran kurang lebih $1 \mathrm{Km}$, dan jalan desa sepanjang kurang lebih $21 \mathrm{Km}$. Selain itu sebanyak 11 jembatan yakni 2 jembatan nasional, 1 jembatan propinsi, 1 jembatan kabupaten, dan 7 jembatan desa. Dalam melaksanakan mobilitasnya masyarakat Desa Bunder menggunakan alat transportasi pribadi seperti motor, mobil atau truk dan angkutan umum seperti bis antar kabupaten/kota, antar provinsi, dan ojek. Sumber air untuk kebutuhan hidup sehari-hari, masyarakat Desa Bunder berasal dari sumur gali dan dari air perpipaan sebagai pelanggan Sistem Penyediaan Air Minum (SPAM) IKK Patuk Oyo Wening Sentosa. Dari 7 pedukuhan di Desa Bunder, sebanyak 5 pedukuhan yang telah mendapat pelayanan air bersih dari SPAM IKK Patuk OyoWening Sentosa.

Kelompok Swadaya Masyarakat Oyo Wening Sentosa, sebelum Oyo Wening Sentosa terbentuk, sekelompok tokoh masyarakat Desa Bunder termasuk Lurah Desa Bunder pada tahun 2004 secara bersama melakukan audience kepada Bupati Gunungkidul guna menyampaikan permasalahan kesulitan air bersih yang dialami masyarakat setempat. Menurut pendapat para tokoh, Desa Bunder adalah desa yang dilalui aliran Sungai Oyo dengan volume air yang cukup besar dan tidak pernah kering, namun demikian masyarakat desa ini selalu mengalami kesulitan untuk memenuhi kebutuhan air bagi rumah tangganya. Cara yang dilakukan pada waktu itu dalam pemenuhan kebutuhan air, antara lain masyarakat mengambil air dari Sungai Oyo yang berjarak $5 \mathrm{s.d} 10 \mathrm{~km}$ dari rumah, atau membeli air dengan tangki seminggu sekali. Air yang diperoleh kurang terjamin kualitasnya. Biaya yang harus dibayar masyarakat setiap tangki berisi 5000 lt. sebesar Rp120.000,00. 
Hasil audience antara masyarakat Desa Bunder dengan Bupati Gunungkidul mendapat respon dan ditindaklanjuti oleh Pemerintah Kabupaten Gunungkidul dengan membawa persoalan tersebut ke DPRD. Hasil pembahasan dengan DPRD, kemudian ditindaklanjuti dengan pengajuan proposal untuk DIP anggaran pemerintah pusat oleh dinas pekerjaan umum Kabupaten Gunungkidul dan satuan kerja PKPAM Daerah Istimewa Yogyakarta. Adanya pengajuan proposal dari PU DIY gayut dengan program Pemerintah yaitu Program Sistem Pengembangan Air Minum (SPAM) Ibu Kota Kecamatan berdasar PP no. 16 Tahun 2005 dan PP No. 23 Th. 2005. Untuk itu melalui Satuan Kerja Pengembangan Kinerja Pengelolan Air Minum Provinsi Daerah Istimewa Yogyakarta, dilaksanakan fasilitasi perencanaan teknis pengembangan sistem penyediaan air minum dengan sasarannya adalah SPAM IKK Patuk yang ada di Kabupaten Gunungkidul. Menurut Kepala Satuan Kerja Dinas PU Provinsi DIY setiap instansi yang terkait dengan masalah pengembangan SPAM diwajibkan terlibat dalam program tersebut. SPAM IKK adalah Sistem Penyediaan Air Minum Ibu Kota Kecamatan, yaitu pelayanan dan pengembangan jaringan distribusi air dengan perpipaan. Menurut pengurus SPAM IKK Patuk Oyo Wening Sentosa, bahwa pada awalnya bantuan berupa sarana prasarana senilai 4,6 milyar. Selain dari APBN, program pengembangan SPAM tersebut mendapat dukungan APBD Kabupaten Gunungkidul pada tahun 2010.

Pada akhir tahun 2009, Ketua Satker PU DIY Ir. Hardjono dalam rapat forum warga di kantor Desa Bunder menyatakan bahwa instalasi pelayanan air bersih yang telah dibangun tidak diserahkan kepada PDAM setempat tetapi kepada masyarakat untuk mengelolanya. Pada saat koordinasi tersebut berdasarkan kesepakatan forum, ditunjuk pengurus sebanyak 5 orang warga Desa Bunder untuk mengelolanya, dengan susunan pengurus sebagai berikut Ketua, Sekretaris, Bendahara dan tenaga teknis dua orang. Pelimpahan secara lisan tersebut disampaikan kepada Lurah Desa pada tahun 2009. Sesuai intruksi Kasatker PK-PAM DIY dan simpulan rapat koordinasi instansi terkait, bahwa penanganan jalannya SPAM dikelola oleh warga masyarakat secara independen yang tergabung dalam Kelompok Swadaya Masyarakat yang sebagian besar berasal dari Desa Bunder di mana letak Intake dan Instalasi Pengolahan Air berada. Oleh pemerintah setempat beserta warga sebagai tokoh masyarakat memberikan nama kelompok swadaya masyarakat pengelola Air bersih perdesaan dengan nama Oyo Wening Sentosa yang artinya air bening yang menyehatkan berasal dari Sungai Oyo. Selanjutnya melengkapi nama lembaga swadaya masyarakat ini ditambahkan sesuai dengan programnya yaitu SPAM IKK Patuk Oyo Wening Sentosa. Personil yang mengelola diberikan Surat Keputusan Lurah Desa Bunder (Hardjono et al. 2013).

Sejarah pembentukan KSM Oyo Wening Sentosa menunjukkan bahwa peran masyarakat dalam upaya meningkatkan kesejahteraannya sangat tinggi yang didukung pemerintah akan memperkuat terwujudnya pemenuhan kebutuhan dasar berupa air bersih. Sebagaimana dinyatakan Dirjen Cipta Karya (2009) bahwa suatu program penyediaan air minum, sanitasi, dan kesehatan akan efektif dan berkelanjutan bila berbasis pada masyarakat melalui pelibatan seluruh masyarakat dan dilakukan melalui pendekatan yang tanggap terhadap kebutuhan masyarakat (demand responsive). Adapun profil secara teknis: Sistem IPA (Instalasi Penjernihan Air) Lengkap, Kontribusinya Baja I Paket, sumber Air Baku berasal dari Sungai Oyo dengan Sumuran, kapasitas Produksi 20 Liter/detik. Luas Tanah 3.500 Meter, status Tanah Kas Desa/Hak Sewa Pakai. Alamat Jl. Yogyakarta-Wonosari Km.28, Pedukuhan Bunder, Desa Bunder, Kecamatan Patuk, Kebupaten Gunungkidul, Daerah Istimewa Yogyakarta. Tujuan: Memenuhi jangkauan pelayanan air minum dan meningkatnya cakupan keluarga atau warga masyarakat di wilayah Kecamatan Patuk dan sekitarnya. Aset Dan Kekayaan Inventaris Barang: Gedung Kantor 3 unit, Ruang Pengelola Bunder 1 unit Ruang Tamu dan Pelayanan Bunder 1 unit Ruang Administrasi dan Komputer Bunder 1 unit Ruang Laborat Bunder 1 unit Ruang Bahan Kimia Bunder 1 unit Ruang Genset Bunder 1 unit Ruang Gedung Peralatan Teknik Bunder 2 unit Ruang Tidur Penjaga Malam Bunder 1 unit Ruang Dapur Bunder 1 unit Kamar Mandi/WC Bunder 1 unit Meubel air dan Perabot Kantor.

Skema Produksi Air Bersih, proses pengolahan dari air baku menjadi air bersih melalui beberapa tahapan. Tahap Awal: air diserap ke dalam sumuran (sumur intake) kemudian dipompa menuju lokasi IPA yang 
berjarak 200 meter. Tahap Pengolahan: air dari sungai menuju Bak Clarifier dikontrol dengan Soda Ash dan Alum sampai air jernih. Tahap Akhir: air jernih masih melalui penyaringan pasir putih pada Bak SandFilter dan melalui proses laborat hingga air dinyatakan layak konsumsi, dengan dikontrol kaporit sebagai pembunuh bakteri.

Profil pelanggan, untuk memperoleh gambaran pelayanan yang diberikan kepada masyarakat sebagai pengguna layanan, dilakukan wawancara mendalam terhadap 50 informan tersebar di 5 desa sasaran layanan Oyo Wening Sentosa. Hasil penelitian menunjukkan bahwa informan perempuan 62 persen, dan laki-laki 38 persen. Banyaknya perempuan sebagai informan karena kebanyakan kepala keluarga laki-laki pergi ke ladang atau ke luar desa untuk bekerja non pertanian. Perempuan menjadi pengelola air di rumah tangga mereka sebagai KK dan istri atau 40 persen KK dan 56 persen istri dan 4 persen anak. Umur informan sebanyak 6 persen kurang dari 30 tahun, 68 persen antara 30-50 tahun dan 26, persen lebih dari 50 tahun. Sebagian besar berusia produktif. Usia produktif kaitannya dengan kebutuhan air bersih, terutama untuk kebutuhan makan, minum dan kesehatan yang cukup besar karena berbagai aktivitas dan keluarganya.

Model pelayanan air bersih: pelayanan air bersih yang diselenggarakan oleh masyarakat Desa Bunder merupakan model yang menjadi media berbagai pemangku kepentingan antara masyarakat, pemerintah, dan kelompok masyarakat yang mendukung kelancaran penyelenggaraan layanan air bersih sebagai kebutuhan dasar. Hasil penelitian memfokuskan bagaimana pelayanan itu diselenggarakan oleh SPAM IKK Oyo Wening Sentosa melalui instrumen organisasi, sumber daya manusia, produk dan kebijakanan dalam pelayanan serta faktor pendukung dan penghambat pelayanan. 1). Organisasi, kelompok swadaya masyarakat Oyo Wening Sentosa terbentuk sesuai dengan kebijakan pemerintah bahwa Program pemerintah yang mendukung peningkatan capaian pelayanan air minum bagi masyarakat kurang mampu di antaranya Sistem Penyediaan Air Minum Ibu Kota Kecamatan (SPAM IKK), program ini memprioritaskan masyarakat sebagai pengelolanya. Menurut Astuti (2009:31-44) sebagai pengguna, masyarakat juga berfungsi sebagai pengelola sarana dan prasarana air bersih. Hal tersebut dapat dilaksanakan mengingat keterbatasan kemampuan pemerintah dalam menyediakan air bersih bagi masyarakat kota maupun di perdesaan. Berdasarkan PP Nomor nomor 23 tahun 2005 arah kebijakan pemerintah dalam peningkatan cakupan dan kualitas pelayanan air minum di antaranya memprioritaskan pembangunan untuk Masyarakat Berpenghasilan Rendah (MBR) di setiap Ibu Kota Kecamatan (IKK). Program pemerintah dalam hal ini Sistem Penyediaan Air Minum Ibu Kota Kecamatan (SPAM IKK) merupakan program yang dilaksanakan dalam upaya pemberdayaan masyarakat memecahkan persoalan pemenuhan kebutuhan dasar berupa air bersih. Dengan terbentuknya organisasi pengelola dan melayani air bersih di Desa Bunder, maka bentuk dan peran serta masyarakat dalam penyelenggaraan sistem penyediaan air minum merupakan penerapan kebijakan pemerintah khususnya dalam peningkatan cakupan dan kualitas pelayanan sebagai prioritas program tahun 2008 di bidang air minum (Dirjen Cipta karya 2009). Keberhasilan masyarakat melalui inisiatif tokoh masyarakat semenjak tahun 2004-2009 dalam mengatasi persoalan cakupan pelayanan air melalui perpipaan dapat ditunjukkan dengan terwujudnya sarana dan prasarana pelayanan air bersih di lingkungan desa mereka, hingga terlaksana pelayanan air bersih bagi warga sampai sekarang. Dalam melakukan operasionalisasi SPAM IKK Patuk Oyo Wening Sentosa, lembaga tersebut mengalami pergantian pengurus dalam kurun waktu 2 tahun masa operasionalnya. Sebagian pengurus mengundurkan diri disebabkan antara lain biaya operasionalnya ditanggung masyarakat dalam hal ini para pengurus. Kemampuan masyarakat dalam memberikan kontribusi terhadap layanan sangat terbatas. Tidak seimbangnya antara pemasukan dan biaya yang harus dikeluarkan, akhirnya kekurangannya biaya harus ditanggung pengelola. Menghadapi persoalan tersebut, ketua KSM Oyo Wening Sentosa melakukan pendekatan kepada salah seorang pengurus untuk bersedia menjadi atau menggantikan dirinya sebagai ketua. Dengan catatan ketua yang baru harus mampu menyediakan dana operasional. Pada tahun 2011 dilakukan pergantian Ketua SPAM IKK Patuk Oyo Wening Sentosa. Ketua yang baru berusaha menyiapkan modal atau dana untuk operasional agar IKK Patuk Oyo Wening Sentosa tetap berjalan. Persoalan baru yang dihadapi pada awal kepemimpinan yang 
baru yaitu Drs. Widi Rakhmanta bahwa beliau masih menerapkan manajemen pengelolaan apa adanya tanpa memperhitungkan bagaimana manajemen perusahaan, sehingga menyebabkan pelaksanaan pelayanan kepada masyarakat dirasa kurang ada kemajuan. Oleh karena itu, berdasarkan rapat pengurus dan pengawas menyepakati adanya perubahan manajemen sebagaimana manajemen perusahaan, ada tanggungjawab dan fungsi yang jelas terhadap jalannya pelayanan SPAM IKK patuk Oyo Wening Sentosa. Perubahan yang dilakukan dalam rangka mengakomodasi berbagai tantangan dan persoalan yang dihadapi, pengurus mengembangkan struktur organisasi seperti pada Gambar 1.

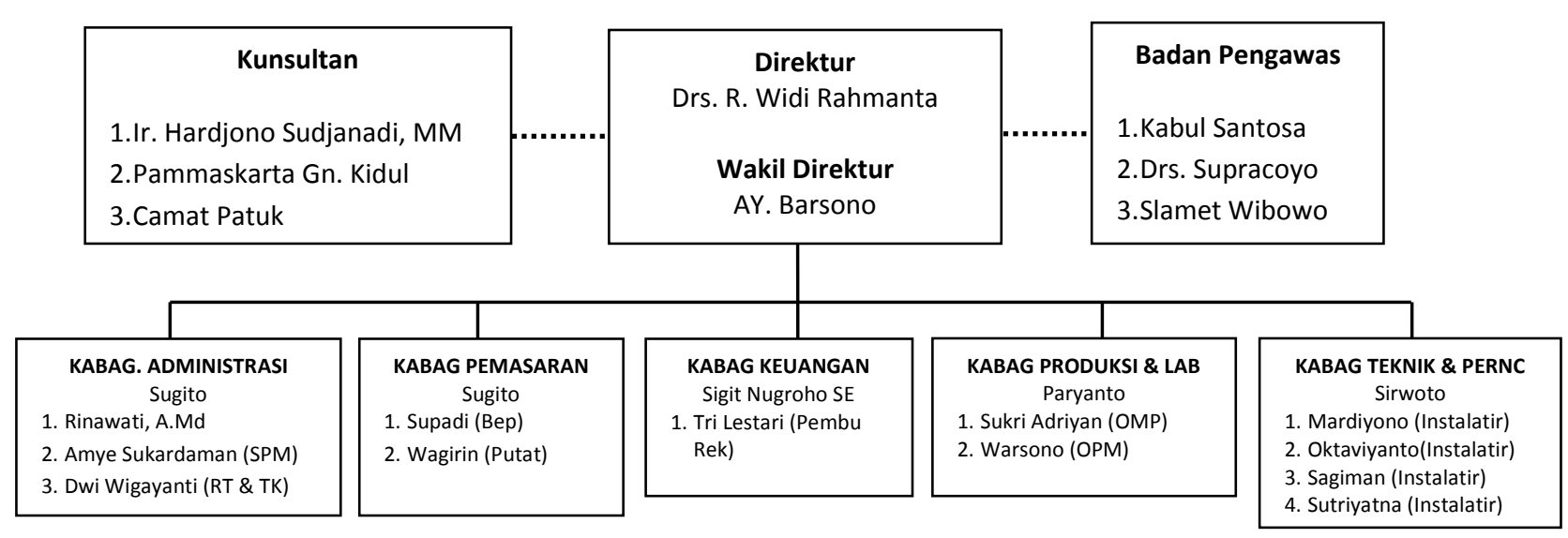

Gambar 1.

Struktur organisasi Pengelola SPAM IKK “oyo wening santosa” gunung kidul Yogyakarta Tahun 2014. Sumber: Oyo Wening Santosa, diunduh hari Minggu, 8 November, 2015

Keberhasilan suatu program, menurut Sujianto (2012) dipengaruhi beberapa faktor salah satunya adalah faktor karakteristik pelaksana. Sikap pelaksana dalam hal ini pengurus SPAM IKK Patuk Oyo Wening Santosa yang sangat positif terhadap penyelesaian masalah air bersih cukup berpengaruh terhadap keberlangsungan program layanan bagi masyarakat. Sebagaimana dinyatakan oleh Direktur SPAM IKK Patuk Oyo Wening Sentosa,"saya bersedia menjual apa saja yang berharga seperti Laptop dan menggadaikan barang berharga lainnya untuk operasional SPAM IKK Patuk Oyo Wening Sentosa".

Demikian pula lurah Desa Bunder Bapak Kabul: "Pemerintah kabupaten tidak mampu menyediakan lahan untuk bangunan sarana pelayanan air bersih, maka Lurah Desa menyediakan tanah kas desa untuk bangunan prasaranan dan sarana layanan seluas $3500 \mathrm{~m} 2$ “.

Pengurus dan Lurah desa Bunder menunjukkan bahwa organisasi akan berhasil apabila memiliki kemanfatan yang besar dan semangat yang besar dari para anggotanya. Keberhasilan pelayanan ini dapat diketahui bertambahan pelanggan sejak tahun 2009 hingga tahun 2014 seperti pada Diagram 1. 


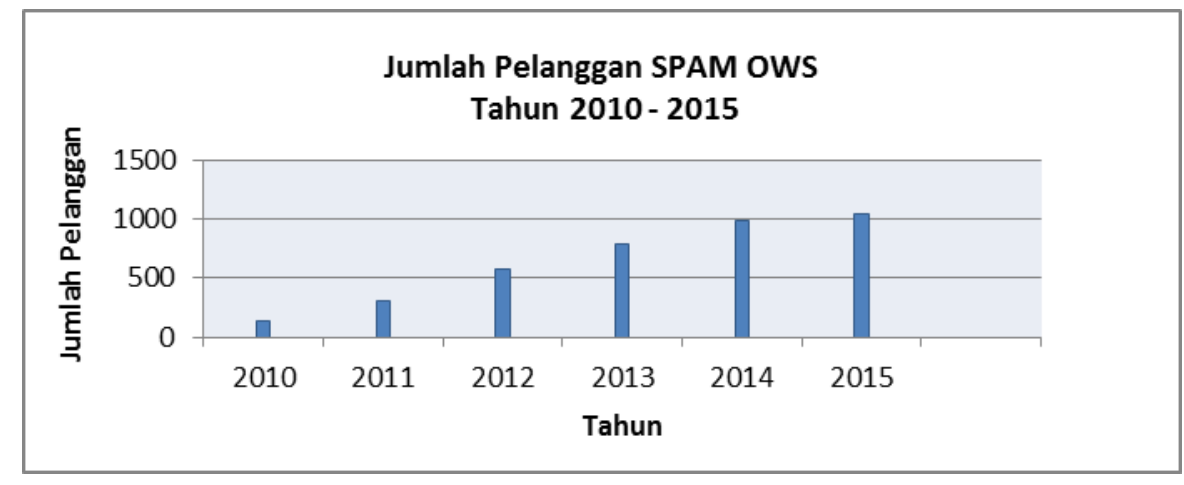

Diagram 1.

Jumlah pelanggan SPAM OWS. Sumber: Kantor SPAM IKK Patuk Oyo Wening Sentosa, 2015

Berdasarkan diagram 1 dapat diketahui perkembangan jumlah pelanggan selama 5 tahun terakhir bertambah. Adapun kapasitas layanan di SPAM IKK Patuk Oyo Wening Sentosa mencapai 1600-2000 SR. Pada saat penelitian dilaksanakan sampai bulan Oktober jumlah pelanggan sebanyak 1170 SR, sehingga masih tersedia peluang sebanyak 830 SR. Semakin bertambahnya pelanggan membutuhkan perhatian yang cukup serius dari para pengelola dalam memberikan pelayanannya. Berdasarkan hasil penelitian selama berdirinya Tahun 2009-2015 pengurus telah mengalami perubahan beberapa personil. Pada awal pengelolaan, pembentukan pengurus SPAM IKK Patuk Oyo Wening Santosa dilakukan Kepala Satuan Kerja dari Dinas PU DIY dilakukan secara menunjuk personil warga Desa Bunder yang dipandang mampu menjalankan operasional pelayanan air bersih sebanyak 5 orang yaitu tokoh masyarakat yang memiliki rasa kepedulian dan kemanfaatannya yang besar apabila menjadi pengurus organisasi pelayanan air bersih bagi masyarakat Desa Bunder. Berbeda lembaga pengelola air yang berlokasi di Pucung Desa Wukirsari Kabupaten Bantul, hasil penelitian Hardjono et al. (2013) menyatakan bahwa PAB Pucung pengurusnya terbentuk atas inisitaif forum warga yang peduli atas bencana gempa bumi di Bantul. Demikian pula penelitian di Desa Karangrejek Kabupaten Gunungkidul menurut Warih et al. (2013) keterlibatan warga dalam pengelolaan air minum perdesaan merupakan keunggulan dari organisasi tersebut.

Beberapa kendala pelayanan dialami pengelola antara lain keterbatasan kemampuan pembiayaan dalam pengadaan cadangan sarana prasarana, mengingat semakin bertambahnya jumlah masyarakat yang membutuhkan air bersih, sehingga biaya operasionalpun semakin membengkak. Namun pendapatan yang diterima pengelola tidak memadai sebagaimana dinyatakan salah satu pengurus SPAM IKK Patuk Oyo Wening Sentosa, "Harga peralatan untuk cadangan apabila ada kerusakan nilainya antara 50 juta rupiah sampai 200 juta rupiah. Padahal kemampuan pendanaan Oyo Wening Sentosa terbatas untuk opeasional saja, sehingga masih terkendala dana untuk pengadaan cadangan peralatan" (Bapak Widhi).

Potensi resiko keberlanjutan organisasi Oyo Wening Sentosa dalam memberikan pelayanan menjadi rentan terhadap berbagai hal yang berkaitan dengan kemampuan-kemampuan pengadaan sarana dan prasarana pelayanan di samping faktor lainnya. Selama ini pengelola belum melakukan evaluasi perhitungan penyusutan barang-barang sebagai modal usaha, dan masih mengandalkan sarana dan prasarana dari program pemerintah tahun 2009 yang masih baik kondisinya. Untuk mengetahui pendapat pelanggan terhadap manfaat adanya kelompok swadaya masyarakat yang memberikan pelayanan air bersih dalam hal ini SPAM IKK OWS, beberapa pertanyaan diajukan, sebab keberlanjutan pelayanan air bersih juga tergantung kepada anggota atau penerima manfaat atas program SPAM IKK tersebut. Apakah organisasi ini keberadaannya selama ini memberikan manfaat bagi masyarakat? Beberapa pendapat masyarakat dirangkum seperti pada Tabel 1. 
Tabel 1.

Pendapat pelanggan tentang manfaat keberadaan SPAM IKK Patuk Oyo Wening Sentosa

\begin{tabular}{cl}
\hline No & \multicolumn{1}{c}{ Keterangan } \\
\hline 1. & Meringankan beban masyarakat ketika musim kemarau, \\
2. Wagino), (Karnoto). \\
3. & Musim kemarau bisa siram tanaman( Ngatiyem) \\
4. & Yang tidak punya sumur lebih mudah (wasini) \\
5. & Membantu banyak perubahan di masyarakat (Parti) \\
7. & Lebih enak, tidak harus menimba (Planti) \\
8. & Saat musim kemarau tidak musti ke sungai (Tumisah) \\
\hline Sumber Data Primer
\end{tabular}

Sumber : Data Primer

Berdasarkan beberapa pendapat masyarakat sebagai pelanggan dapat diketahui bahwa adanya organisasi masyarakat yang melayani air bersih telah menyebabkan terjadinya perubahan yang postif terhadap kondisi sosial ekonomi mereka dan lingkungan. Hal tersebut menunjukkan bahwa kelompok swadaya masyarakat Oyo Wening Sentosa yang melaksanakan program pelayanan air bersih telah diterima masyarakat, baik dari aspek sosial ekonomi dengan harapan pemberi pelayanan maupun yang dilayani sama merasakan manfaat. Beban sosial dan ekonomi dapat dikurangi. Di samping itu, sifat orang desa yang masih menjunjung hubungan sosial antara pengurus dengan masyarakat yang sama-sama warga Desa Bunder, maka aspek hubungan sosial tersebut akan mendukung keberlangsungan organisasi tersebut. 2) Sumber Daya Manusia, menurut pengertiannya, pelayanan adalah produk-produk yang kasat mata (tidak dapat diraba) yang melibatkan usaha-usaha manusia dan menggunakan peralatan (Ivancevich et al. 1997). Pelayanan merupakan sesuatu yang melekat dalam kehidupan manusia sehari-hari. Adapun pengertian dari pelayanan tersebut menurut Gronroos dalam Ratminto (2005) (Hardiyansyah 2011). Pelayanan adalah suatu aktivitas atau serangkaian aktivitas yang bersifat tidak kasat mata yang terjadi sebagai akibat adanya interaksi antara konsumen dengan karyawan atau hal-hal lain yang disediakan oleh perusahaan pemberi pelayanan yang dimaksudkan untuk memecahkan permasalahan konsumen atau pelanggan. Berdasarkan pendapat para ahli tersebut, dapat disimpulkan dalam pelayanan sumber daya manusia sangat diperlukan untuk memecahkan persoalan permasalahan pelanggan atau konsumen. Berdasarkan wawancara dengan pengurus SPAM IKK Patuk Oyo Wening Sentosa, bahwa jumlah pengelola layanan semenjak tahun 2009 telah mengalami perubahan dan penambahan. Pada tahun 2009 jumlah pengelola sebanyak 5 orang, dan pada tahun 2015 sebanyak 10 orang. Adanya perubahan dan penambahan jumlah pengelola dikarenakan pihak manajemen dalam hal ini direktur dan pengawas sepakat menerapkan pengelolaan yang lebih baik sebagaimana diterapkan dalam model perusahaan, sehingga pola kerja pengelola lebih terstruktur dan efektif. Dampak yang diharapkan adalah pelanggan yang jumlahnya semakin bertambah memperoleh layanan air bersih sebagaimana yang dibutuhkan dengan layanan yang berkualitas. Perubahan yang diusulkan Ketua Oyo Wening Sentosa Kepada Lurah Desa Bunder sebagai pengawas yaitu perubahan struktur organisasi dan penyebutan personil dalam struktur organisasi tersebut. Sebelumnya dalam struktur organisasi susunan pengurus terdiri dari Ketua, wakil ketua, sekretaris, bendahara dan teknisi. Oleh Ketua struktur organisasi tersebut dianggap konvensional, seperti pernyataan beliau :

...beberapa kali instruksi yang saya berikan kepada teman-teman pengelola lainnya untuk perbaikan pelayanan tidak berjalan. Saya pelajari dan saya renungkan bagaimana merubah pola kerja temanteman agar usaha ini betul-betul menguntungkan seperti dalam perusahaan.Ada tugas yang jelas dengan dan instruksi atasan dapat berjalan, karena dengan struktur yang lama instruksi kerja atasan dianggap pembicaraan seperti teman sejawat saja.Tidak dijalankan tidak merasa bersalah, padahal tanggung jawab kepada pelanggan cukup besar (Pak Widi).

Perubahan struktur organisasi diusulkan kepada rapat pengurus dan diterima serta dilaksanakan pada tahun 2011. Perubahan itu membawa perubahan pola kerja yang lebih positif bagi seluruh pengelola SPAM IKK Patuk Oyo Wening Sentosa. Metode yang diterapkan secara psikologis menambah kepercayaan pengelola 
untuk memberi pelayanan yang baik. Ditinjau dari segi pendidikan, sebagian besar tingkat menengah ke atas. Direktur berpendidikan Strata 1yang saat ini sebagai guru SD yang masih aktif. Jumlah pengelola mulai diadakan penambahan tenaga pada tahun 2012. Hal ini disebabkan jumlah pelanggan cukup banyak pertambahannya. Kondisi tersebut menuntut tanggungjawab pengelola yang lebih besar. Selain pengelola atau pelaksana, terdapat struktur organisasi pengawas yang unsurnya dari pemerintah, BPD dan konsumen atau pelanggan.

Bagaimanakah pengelola SPAM IKK Patuk Oyo Wening Santosa secara kualitas memberikan layanan khususnya kepada pelanggan. Beberapa pelanggan memberikan pendapat tentang lembaga yang dikelola oleh masyarakat tersebut. Mengetahui pendapat pelanggan, maka partisipasi warga terhadap model layanan air bersih yang diselenggarakan SPAM IKK Patuk Oyo Wening santosa akan berpengaruh terhadap keberlangsungan lembaga dan lebih terjamin pelayanan air bersih di lingkungannya.

Tabel 2.

Pendapat pelanggan tentang petugas pelayanan SPAM IKK OWS

\begin{tabular}{cl}
\hline No & \multicolumn{1}{c}{ Keterangan } \\
\hline $1 . \quad$ & Biasanya dalam hal pembayaran rutin tiap bulannya, masyarakat membayarnya \\
& secara kolektif/diambil oleh Bapak Pardi, dengan menambah ongkos tambahan 2.000 \\
& sebagai pengganti transport dan tenaga untuk mengantarkan uang ke kantor. Untuk \\
penampilan petugas sudah rapi, dan terkadang memakai seragam. Kedisiplinan \\
petugas cukup baik, petugas datang rutin untuk pengecekan dan perawatan kalaupun \\
ada kerusakan biasanya langsung diperbaiki. Kemudahan akses pelanggan dalam \\
permohonan pelayanan sangat dipermudah, pelanggan tidak perlu datang ke kantor \\
karena petugas biasanya yang ke lapangan, penggunaan alat bantu dalam pelayanan \\
tidak tahu, karena pelanggan belum pernah datang ke kantor \\
2. Penampilan petugas sudah rapi, proses pelayanan mudah, kedisiplinan sudah bagus, \\
akses pengajuan permohonan pelayanan mudah \\
3. Petugasnya baik, pelayanan mudah \\
B. Bagus, pelayanannya juga baik
\end{tabular}

Sumber: Data Primer

Tabel 3.

Pendapat pelanggan terhadap respon petugas SPAM IKK Oyo Wening Sentosa dalam menanggapi pengaduan pelanggan saat membutuhkan

\begin{tabular}{cl}
\hline So & \multicolumn{1}{c}{ Keterangan } \\
\hline 1. & $\begin{array}{l}\text { Merespon pelanggan yang ingin mendapatkan pelayanan dengan cepat, tepat, dan } \\
\text { cermat }\end{array}$ \\
2. & $\begin{array}{l}\text { Respon petugas terhadap pelanggan bagus baik itu mengenai keluhan maupun } \\
\text { proses pelayanan }\end{array}$ \\
3. & Apabila ada kerusakan langsung direspon \\
4. & Direspon, langsung ditindaklanjuti \\
5. & Merespon cepat sesuai antrian \\
6. & Pipa bocor, ditelepon langsung datang \\
\hline
\end{tabular}

Sumber: Data Primer

Tabel 2 menunjukkan bahwa pelayanan yang dilakukan petugas SPAM IKK Patuk Oyo Wening Sentosa sudah dirasakan cukup memenuhi harapan konsumen terutama pelayanan umum dan khususnya pengaduan. Hal tersebut tidak terlepas dari manajemen yang telah dilaksanakan selama ini dalam upaya meningkatkan kualitas dari segi internal OWS. Manajemen pelayanan menurut Ratminto (2005), manajemen pelayanan yang baik akan dapat diwujudkan apabila penguatan posisi tawar pengguna jasa pelayanan mendapat 
prioritas utama. Pengguna jasa diletakkan di pusat yang mendapatkan dukungan dari: 1) sistem pelayanan yang mengutamakan kepentingan masayarakat, khususnya pengguna jasa 2) kultur pelayanan dalam organisasi penyelenggara pelayanan, 3) sumber daya manusia yang berorientasi pada kepentingan pengguna jasa.

Zeithaml et al. (1988) mengemukakan beberapa indikator pelayanan, yaitu 1) tangibles (ketampakan fisik), artinya petampakan fisik dari gedung, peralatan, pegawai, dan fasilitas-fasilitas lain yang dimiliki provider, 2) realibility atau realibilitas adalah kemampuan pegawai untuk menyelenggarakan pelayanan yang dijanjikan secara akurat, 3) responsiveness atau responsivitas adalah kerelaan untuk menolong pelanggan dan menyelenggarakan pelayanan dengan ikhlas, 4) assurance atau kepastian adalah pengetahuan dan kesopanan para pegawai dan kemampuan mereka memberikan pelayanan kepada pelanggan, 5) produk dan kebijakan, dalam memperoleh layanan air bersih, OWS mengeluarkan beberapa peraturan yang membantu warga agar memiliki jaminan pelayanan melalui posedur menjadi calon pelanggan dan sebagai pelanggan meliputi administrasi pendaftaran, pelayanan pelanggan dan pengaduan.

Untuk memperoleh pelayanan air bersih, calon pelanggan lebih dahulu melakukan pendaftaran guna memenuhi persyaratan administrative, dengan langkah-langkah yang dilakukan sebagai berikut: pertama, pelanggan datang ke kantor untuk mengambil formulir isian tentang identitas serta lokasi calon pelanggan. Persyaratan yang dibutuhkan yaitu 1 lembar photocopy kartu keluarga/C1 dan photocopy KTP Kepala keluarga, kemudian mengisi formulir calon pelanggan. Kemudian persyaratan diserahkan ke bagian administrasi. Pada saat itu pula calon pelanggan dapat langsung membayar biaya pemasangan sarana prasarana sebanyak Rp. 1.000.000,- atau dapat juga menitip sebagian.

Bagian administrasi memberikan penugasan kepada bagian teknis untuk melakukan survei lokasi calon pelanggan dengan beberapa instrumen ukuran antara lain yaitu: Jarak rumah calon pelanggan dengan saluran induk dan ketinggian tempat rumah atau lokasi instalasi tempat penerima layanan air bersih. Hasil survey yang dilakukan oleh bagian teknis dapat menjadi indikator apakah calon pelanggan diterima atau ditolak. Apabila persyaratan dari segi teknis terpenuhi, maka bagian teknis meminta kepada kelompok kerja instalatir untuk memasang instalasi air. Kelompok instalatir tersebut memasang instalasi air berdasarkan titik-titik yang telah dipetakan oleh bagian teknis.

Bagi pelanggan, pelayanan yang diterapkan yaitu pelanggan akan dicatat jumlah pemakaian air per bulan oleh petugas pencatat water meter atas permintaan bagian teknis. Petugas pencatat air dapat berasal dari warga setempat atau petugas dari SPAM IKK Oyo Wening Sentosa. Apabila pencatat watermeter berasal dari warga setempat, mereka adalah warga yang telah memperoleh ijin dari SPAM IKK OWS. Selain mencatat pemakaian air, petugas juga diberikan pekerjaan tambahan yaitu mencatat hal-hal yang dipandang merugikan pelanggan ataupun merugikan OWS seperti adanya kebocoran pipa. Hasil pencatatan pemakaian air diserahkan ke bagian teknis, kemudian dari bagian teknis diserahkan ke bagian administrasi untuk direkap jumlah pemakaian air selama satu bulan. Hasil rekapitulasi di bagian administrasi, selanjutnya hasilnya diserahkan kepada bagian keuangan untuk diperhitungkan biaya yang akan dibayar pelanggan. Pelanggan diberikan jadwal pembayaran biaya pemakaian air mulai tanggal 1-20 pada setiap bulannya. Beberapa alternatif pembayaran biaya pemakaian air dapat dipilih pelanggan, yaitu pertama pelanggan menyetor langsung ke SPAM IKK OWS, kedua pelanggan menyetor uang kepada kolektor lembaga kemasyarakatan seperti Karang Taruna atau PKK, ketiga dapat menyetor ke kolektor individual. Oleh karena sulitnya medan dan jarak rumah pelanggan dengan kantor SPAM IKK Patuk OWS, kadang pelanggan menitip uang setoran kepada petugas jika bertemu di jalan. Apabila uang biaya pemakaian air sudah terkumpul di kolektor, selanjutnya uang disetorkan ke bagian keuangan. Oleh bagian keuangan selanjutnya diserahkan ke bagian administrasi untuk dicatat, apakah pelanggan ada yang menunggak atau tidak. Apabila pelanggan yang menunggak pembayaran, maka akan terkena denda. Namun demikian belum semua pelanggan menepati waktu pembayaran, sehingga petugas SPAM IKK Patuk OWS aktif menagih ke rumah pelanggan. Kondisi tersebut merupakan salah satu gap antara pelanggan dan SPAM IKK Patuk sebagaimana yang dinyatakan oleh Zeithaml et al. (1988) bahwa dalam 
layanan kadangkala terjadi gap antara pemberi layanan dan yang menerima layanan. Apabila pelanggan merasa tidak puas dengan pelayanan yang diberikan, pelanggan dapat menyalurkan aspirasinya langsung ke SPAM IKK Patuk OWS melalui telepon, handphone maupun langsung ke kantor OWS. Dari hasil penelitian dapat diketahui bahwa kelompok swadaya masyarakat Oyo wening Sentosa telah menerapkan pelayanan dengan kualitas yang memenuhi harapan pelanggan, sesuai dengan dimensi yang dikemukakan Zeithamll et al. (1988) bahwa kualitas pelayanan dengan indikator petugas merespon setiap pelanggan yang ingin mendapatkan pelayanan, petugas melakukan pelayanan dengan cepat, tepat dan cermat (Hardiyansyah 2011).

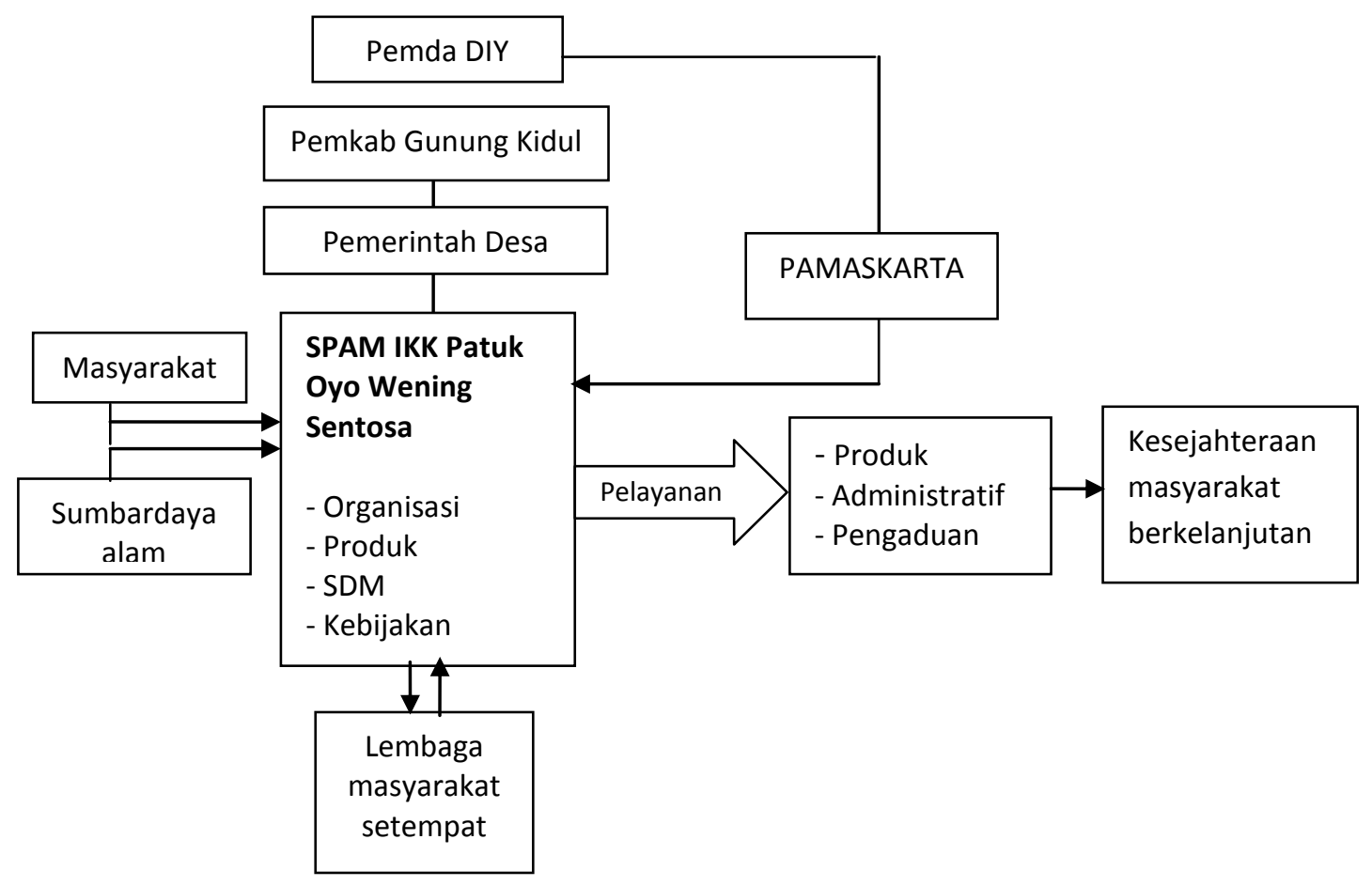

Gambar 2.

Model pelayanan air bersih perdesaan SPAM IKK Patuk Oyo Wening Sentoso

Model Pelayanan Air bersih SPAM IKK Patuk Oyo Wening Sentosa sebagaimana dalam gambar 2 merupakan sinergi masyarakat yang diwakili kelompok Oyo Wening Sentosa bekerja sama dengan berbagai pemangku kepentingan untuk memberikan kesempatan masyarakat memperoleh layanan air bersih. Pemerintah yang berjenjang melaui dinas terkait yaitu PU DIY dan PU Kabupaten Gunungkidul memberikan perhatian yang cukup besar terhadap penyelenggaraan pelayanan air bersih kepada masyarakat desa dengan bantuan program Sistem Penyediaan Ibu Kota Kecamatan (SPAM IKK). Hal tersebut menunjukkan peran pemerintah dalam mendukung peningkatan capaian akses masyarakat terhadap air bersih. Masyarakat sebagai komunitas yang membutuhkan pelayanan dan yang melaksanakan pelayanan serta potensi sumber daya alam berupa bahan baku air dari Sungai Oyo merupakan pendorong dan pendukung kuat terlaksananya pelayanan air bersih oleh KSM Oyo Wening Sentosa. Lembaga masyarakat setempat yang anggotanya memiliki keahlian tentang instalasi air minum merupakan mitra dalam memperlancar teknis pelayanan di tingkat rumah tangga.

Paguyuban Air Minum Masyarakat Yogyakarta (Pamaskarta) sebagai wadah kelompok-kelompok masyarakat yang mengelola air minum/air bersih merupakan lembaga di mana Oyo Wening Sentosa memperoleh tempat untuk koordinasi dan konsultasi tentang dinamika pelayanan air minum di Daerah 
Istimewa Yogyakarta. Hasil dari sinergi berbagai pihak dan pengelolaan lingkungan masyarakat dan sumber daya alam menghasilkan pelayanan yang dibutuhkan masyarakat yang berupa air bersih sebagai produk utama dan pelayanan administratif serta pengaduan. Pelayanan selama ini yang diberikan oleh kelompok swadaya masyarakat Oyo Wening Sentosa mampu memberikan perubahan sosial ekonomi bagi masyarakat desa sebagai pelanggan dan masyarakat di lingkungan, sehingga diharapkan memberikan kesejahteraan secara berkelanjutan.

Faktor-faktor pendukung antara lain: 1) Sumber Daya Manusia, pelayanan air bersih yang diselenggarakan oleh lembaga swadaya masyarakat merupakan wujud kesadaran masyarakat setempat untuk mengatasi permasalahannya sendiri. Untuk itu mereka yang terlibat dalam pengelolaan air bersih adalah faktor pendukung kemudahan akses masyarakat memperoleh pelayanan air bersih. Selain itu kekompakan antar petugas dalam melayani masyarakat yang mereka sebut sebagai budaya gotong royong masih melekat diterapkan oleh karyawan SPAM IKK patuk OWS tanpa meninggalkan profesionalitasnya, sehingga kearifan lokal tersebut mendukung terselenggaranya pelayanan air bersih, 2) Sumber daya alam berupa air yang tidak pernah kering Sungai Oyo sebagai bahan baku utama pelayanan kepada masyarakat desa merupakan potensi yang dapat dimanfaatkan masyarakat seluas-luasnya untuk kesejahteraan, 3) Dukungan pemerintah, berupa kebijakan pemerintah memberikan dana untuk sarana dan prasarana terselenggaranya pelayanan air bersih SPAM IKK OWS, memberikan semangat dan motivasi kepada kelompok masyarakat untuk dapat memberikan pelayanan sebaik-baiknya kepada masyarakat. Sarana produksi berupa peralatan dalam menampung air, mampu melayani pelanggan memiliki kapasitas 2000 SR akan meringankan beban sosial ekonomi masyarakat setempat yang tidak ternilai 4) Jumlah pelanggan semakin bertambah menunjukkan bahwa pelayanan yang diberikan oleh OWS sangat dibutuhkan masyarakat.

Faktor penghambat pelayanan air bersih perdesaan, sebagaimana yang dinyatakan oleh Zeithaml et al. (1988) bahwa dalam melaksanakan pelayanan pasti ada gap di antaranya: 1) masih kurangnya pengetahuan petugas teknisi khususnya dalam memperbaiki peralatan sehingga apabila ada kerusakan tidak segera terselesaikan, 2) legalitas pelayanan air bersih perdesaan dalam bentuk peraturan daerah atau peraturan sejenis belum dimiliki sebagai payung hukum keberadaan lembaga SPAM IKK Patuk OWS. Hal tersebut menjadikan pengelola kurang percaya diri dalam memberikan pelayanan dan upaya pengembangannya, 3) dana terbatas untuk pengadaan sarana dan parasarana apabila ada kerusakan, karena tarif yang ditetapkan masih rendah mengingat kondisi ekonomi masyarakat setempat masih relatif rendah. Adapun tarif pemakaian sebanyak $1-10 \mathrm{~m}^{3}$ sebesar Rp 3.500,- per $\mathrm{m}^{3}$ dan lebih dari $10 \mathrm{~m}^{3}$ sebesar Rp. 4000,- per $\mathrm{m}^{3}$. Apalagi masih ada sebagian masyarakat yang kurang peduli terhadap kelancaran pelayanan air bersih antara lain membayar biaya pemakaian sering terlambat, 4) di bidang sarana dan prasarana memang dirasakan kesulitan memperoleh komponen tertentu pendukung sarana prasarana, sehingga memerlukan waktu dalam pengadaannya. Kondisi tersebut menjadi lemahnya dalam proses pelayanan.

\section{Simpulan}

Hasil penelitian dapat ditarik simpulan bahwa kegiatan pelayanan air bersih perdesaan dengan model pelayanan yang diterapkan dapat menunjukkan perubahan akses masyarakat terhadap air bersih. Dengan model pelayanan air bersih perdesaan yang dikelola oleh masyarakat, telah membantu mempermudah akses terhadap pemenuhan kebutuhan dasar berupa air bagi kehidupan rumah tangga, terutama bagi usia produktif. Waktu yang digunakan untuk memperoleh air dapat dipersingkat dari waktu yang tersisa sebelumnya.

Di bidang kelembagaan, organisasi yang ada dalam strukturnya yaitu bagian-bagian telah berfungsi sehingga dapat melayani pelanggan sebagaimana permintaan kebutuhan air. Dampak positif yang dirasakan masyarakat antara lain ekonomi masyarakat lebih meningkat, karena dana untuk penyediaan air lebih murah daripada sebelum ada pelayanan SPAM IKK Patuk Oyo Wening Sentosa. Ketersediaan air 
bersih telah terjamin kualitasinya. Pelayanan air bersih di masyarakat perdesaan cukup fleksibel, sehingga membuka peluang kerja bagi masyarakat desa secara langsung maupun tidak langsung. Secara tidak langsung, tersedianya air bagi rumah tangga membuka kesempatan kerja seperti usaha laundry, warung makan dan lainnya.

Faktor penghambat dalam pelayanan pada model yang diterapkan selama ini berasal dari berbagai pihak, dari masyarakat, instansi OWS sendiri, pemangku kepentingan lain juga faktor alam. Untuk itu dalam pemecahan permasalahannya dibutuhkan kerjasama berbagai pihak pemangku kepentingan agar keberlangsungan pelayanan air bersih bagi kesejahteraan masyarakat dapat terwujud.

Berhubung pentingnya legalitas dalam usaha pelayanan kepentingan masyarakat untuk kebutuhan dasar, maka penelitian ini memberikan rekomendasi bahwa legalitas pengelolaan usaha pelayanan air bersih menjadi prioritas lembaga SPAM IKK Patuk Oyo Wening Sentosa. Usaha tersebut dengan jalan menjalin hubungan yang sifatnya konsultatif dan koordinatif dengan berbagai pihak untuk memperoleh legalitas organisasi.

Berkaitan dengan faktor pendukung dan penghambat pelayanan air bersih perdesaan, maka SPAM IKK Patuk Oyo Wening Sentosa harus membuat rencana program kerja dengan menentukan skala prioritas jangka panjang, jangka menengah dan jangka pendek agar diperoleh peningkatan kualitas pelayanan sebagaimana diharapkan oleh semua pihak yang berkepentingan.

\section{Daftar Pustaka}

Astuti ND (2009) Kebijakan pemerintah dalam mendorong usaha penyediaan air bersih berbasis masyarakat. Jurnal Ilmu Sosial Alternatif X (1).

Dirjen Cipta Karya (2009) Ruang Lingkup Kegiatan Program WSL IC-III/PAMSIMAS. Jakarta: PAMSIMAS. Direktorat Jendral Cipta Karya Departemen Pekerjaan Umum RI.

Hardjono, Astuti ND, dan Putranti CSW (2013) Model pengelolaan air bersih desa di Bantul. Jurnal Komunitas 5 (2): 2185-195.

Hardiansyah (2011) Kualitas Pelayanan Publik. Yogyakarta: Penerbit Gava Media.

Ivancevich MJ, Lorenzi P, Skinner SJ, \& Crosby PB (1977) Management: Quality and Competitiveness. New York: McGraw-Hill Companies.

Moleong MJ (2006) Metode Penelitian Kualitatif. Bandung: Remaja Rosdakarya.

Ratminto \& Winarsih AS (2005) Manajemen Pelayanan. Yogyakarta: Pustaka Belajar.

Sony (2014) Gap cakupan pelayanan air minum masih cukup besar. http://www.pu.go.id/main/ view_pdf/6282.

Sujianto MH dan Sahuri C (2012) Implementasi program penyediaan air bersih di daerah perkotaan. Jurnal Kebijakan Publik 3 (2):119-123.

Undang-Undang Republik Indonesia Nomor 7 (2004) Tentang Sumber Daya Air.

Warih HA dan Fajarwati A (2013) Kajian air bersih berbasis komunitas (Studi kasus di Desa Karangrejek, Gunungkidul). Jurnal Bumi Indonesia 2 (1):187-196.

Zeithaml VA, Parasuraman A, \& Berry LL (1988) SERVQUAL: A multiple-item scale for measuring consumer perceptions of service quality. Journal of Retailing 64 (1): 12-40. 